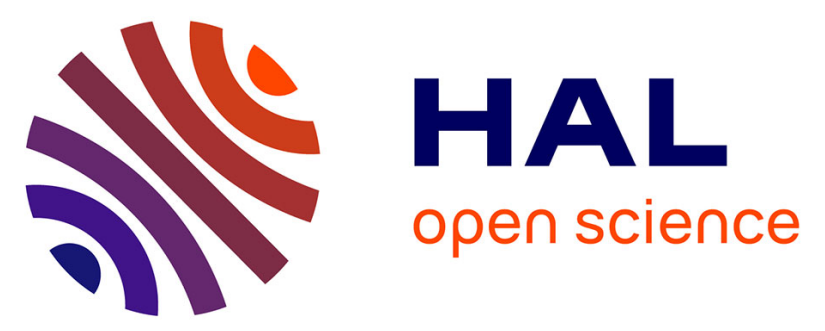

\title{
Investigation of aggregation and acid dissociation of new cationic exchangers for liquid-liquid extraction
}

\author{
Kateryna Omelchuk, Moncef Stambouli, Alexandre Chagnes
}

\section{To cite this version:}

Kateryna Omelchuk, Moncef Stambouli, Alexandre Chagnes. Investigation of aggregation and acid dissociation of new cationic exchangers for liquid-liquid extraction. Journal of Molecular Liquids, 2018, 262, pp.111-118. 10.1016/j.molliq.2018.04.082 . hal-01813755

\section{HAL Id: hal-01813755 \\ https://hal.science/hal-01813755}

Submitted on 12 Jun 2018

HAL is a multi-disciplinary open access archive for the deposit and dissemination of scientific research documents, whether they are published or not. The documents may come from teaching and research institutions in France or abroad, or from public or private research centers.
L'archive ouverte pluridisciplinaire HAL, est destinée au dépôt et à la diffusion de documents scientifiques de niveau recherche, publiés ou non, émanant des établissements d'enseignement et de recherche français ou étrangers, des laboratoires publics ou privés.

\section{(1) (1) $\$$}

Distributed under a Creative Commons Attribution - NonCommercial - NoDerivatives| 4.0 


\section{Accepted Manuscript}

Investigation of aggregation and acid dissociation of new cationic exchangers for liquid-liquid extraction

Kateryna Omelchuk, Moncef Stambouli, Alexandre Chagnes

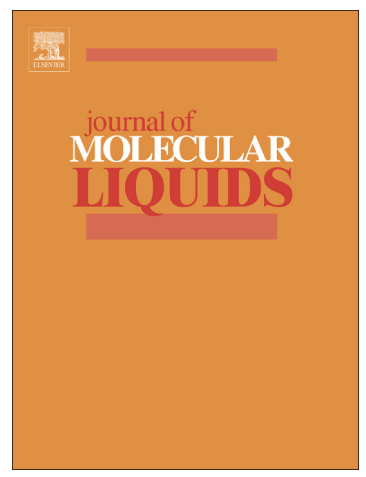

PII:

S0167-7322(18)30466-5

DOI: doi:10.1016/j.molliq.2018.04.082

Reference: MOLLIQ 8985

To appear in: Journal of Molecular Liquids

Received date: 28 January 2018

Revised date: 15 March 2018

Accepted date: 16 April 2018

Please cite this article as: Kateryna Omelchuk, Moncef Stambouli, Alexandre Chagnes, Investigation of aggregation and acid dissociation of new cationic exchangers for liquidliquid extraction. The address for the corresponding author was captured as affiliation for all authors. Please check if appropriate. Molliq(2017), doi:10.1016/j.molliq.2018.04.082

This is a PDF file of an unedited manuscript that has been accepted for publication. As a service to our customers we are providing this early version of the manuscript. The manuscript will undergo copyediting, typesetting, and review of the resulting proof before it is published in its final form. Please note that during the production process errors may be discovered which could affect the content, and all legal disclaimers that apply to the journal pertain. 


\title{
Investigation of aggregation and acid dissociation of new cationic exchangers for liquid-liquid extraction
}

\author{
Kateryna Omelchuk ${ }^{\mathrm{a}}$, Moncef Stambouli ${ }^{\mathrm{b}}$, Alexandre Chagnes, ${ }^{\mathrm{c}^{*}}$ \\ ${ }^{a}$ PSL Research University, Chimie ParisTech-CNRS, Institut de Recherche de Chimie \\ Paris, 11 rue Pierre et Marie Curie, 75005 Paris, France \\ ${ }^{b}$ Centralesupelec, Paris-Saclay University, 3 Rue Joliot Curie 91192 Gif-sur-Yvette \\ ${ }^{c}$ Université de Lorraine, CNRS, GeoRessources, F- 54000 Nancy, France
}

\begin{abstract}
Potentiometric titration and Vapour Pressure Osmometry were used to characterise the acidic properties in an acidic chloride solution and the aggregation behaviour in $n$ heptane of a series of four extractants synthesized in the present work and derived from bis-(2-ethyl-hexyl-phosphoric) acid, a commercial extractant noted D2EHPA. Four other commercial organophosphorus extractants (D2EHPA, Cyanex 272, Cyanex301, Ionquest 801) were also characterized by these techniques. Their hydrophobicity was also investigated by determining the partition coefficient of the monomeric form between an acidic chloride solution and $n$-dodecane. The pka values, the dimerization and trimerisation constants were deduced from experimental results by means of appropriate physicochemical models.
\end{abstract}

Keywords: Acidic dissociation constant; cationic exchanger; dimerisation; physicochemistry; trimerisation; solvent extraction.

TO WHOM CORRESPONDENCE SHOULD BE ADDRESSED (ALEXANDRE.CHAGNES@UNIV-LORRAINE.FR) 


\section{INTRODUCTION}

Solvent extraction is a mature technology that is used in industry for the recovery of metals from leaching solutions. In solvent extraction, the aqueous leaching solution is contacted with an organic phase containing an extractant or a mixture of extractants diluted in an aliphatic or an aromatic diluent. Both immiscible phases are mixed and settled in mixerssettlers. Afterwards, metals in the loaded organic phase are stripped with an appropriate aqueous solution before performing further treatments such as precipitation/crystallisation or electrolysis.

Extractants used in solvent extraction are divided into three families: (i) cationic exchangers such as bis-(2-ethylhexyl)phosphoric acid (D2EHPA), bis-(2,4,4trimethylpentyl)phosphinic acid (Cyanex 272), etc., (ii) anionic exchangers such as tri-noctylamine (Alamine ${ }^{\circledR} 336$ ), Trioctylmethylammonium chloride (Aliquat@ 336), etc. and (iii) solvating agents such as tri-n-octylphosphine oxide (TOPO), tri-n-butylphosphate (TBP), etc. [1]. The choice of the solvent depends on the nature of the leaching solution, the nature of the metals to be extracted and the nature of the impurities present in the leaching solution. The search for new extractants is a real challenge in the development of liquid-liquid extraction processes since it is mandatory to treat more and more complex ores or secondary resources in an efficient and economical way. Cationic exchangers are used in many applications such as the recovery of cobalt from acidic sulfate or chloride media [2-4], uranium from concentrated phosphoric acid $[5,6]$, etc.

Although solvent extraction seems easy to implement, its physicochemistry is complex because the system contains two phases in which many equilibria occur as well as an interphase. Furthermore, the non-ideal behaviour of the system due to high concentration in aqueous phase also increases the complexity of the physicochemistry of liquid-liquid extraction.

In solvent extraction chemistry, the knowledge of the acidity constants and the interaction constants between the components of an extracting system is essential to clarify processes occurring in solution and to ascertain the stoichiometry of the extracted species $[7,8]$. In this paper, the physicochemical properties of new synthesized and commercial organophosphorus cationic exchangers have been investigated (Table 1). These extractants could be used for the recovery of cobalt, nickel, and manganese from acidic sulfate or chloride media. They were also studied for the recovery of uranium from concentrated phosphoric acid providing that they are used in mixture of solvating agents such as tri-n-octylphosphine or tri-n- 
butylphosphate. The use of these extractants instead of more classical ones such as D2EHPA or Cyanex 272 may be beneficial since the addition of oxygen atoms in the hydrophobic chains could advantageously lead to a decrease of the $\mathrm{pK}_{\mathrm{a}}$ values, and therefore an increase of metal extraction efficiency at low $\mathrm{pH}$, while the increase of the steric hindrance of the molecule may improve the selectivity of the extractants and improve metal separation in solvent extraction processes. In particular, aggregation behaviour and acidic dissociation of the molecules have been determined by means of potentiometric and vapour pressure osmometry (VPO) measurements combined with appropriate models.

\section{Material and Methods}

\subsection{Synthesis of organophosphorus acids}

Phosphorus trichloride (Fisher Scientific, purity 99\%), pyridine (Fisher Scientific, purity 99\%), 1-octanol (Fisher Scientific, purity 99\%), 2-methyl-1-propanol (Fisher Scientific, purity 99\%), 1-butanol (Fisher Scientific, purity 99,5\%), lithium aluminium hydride (Fisher Scientific, purity 95\%, powder), iodine (Fisher Scientific, purity 99\%), sodium (Sigma Aldrich purity $\geq 99.8 \%$ ), ethylene glycol butyl ether (Sigma Aldrich, purity $\geq 99 \%$ ), 6undecanone (TCI, purity >98 \%), 2-ethyl-1-hexanol (TCI, purity >99,5\%) and 1,3-dichloro-2propanol (TCI, purity $>98 \%$ ) were used as delivered.

The synthesis of BiDiBOPP was performed according to the procedure previously published by Beltrami et al. [6] (Scheme 1).

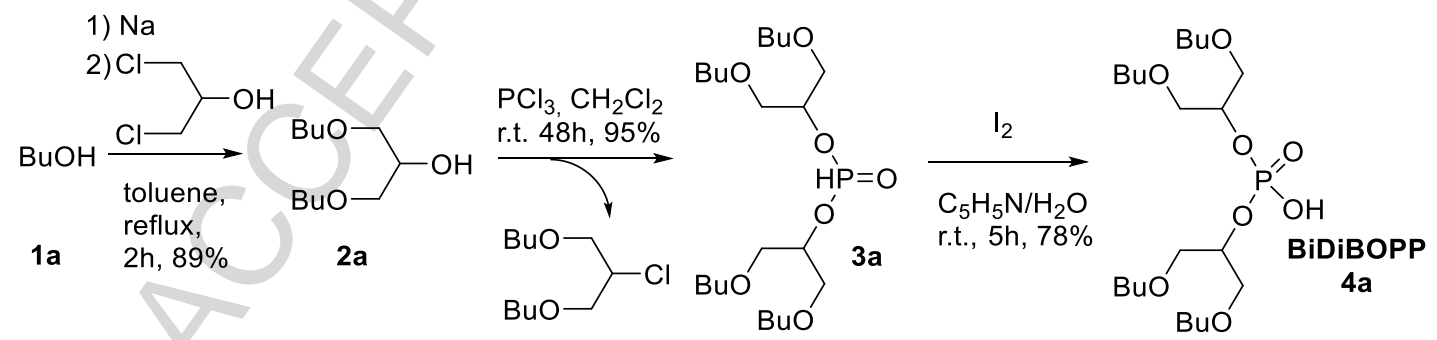

Scheme 1

The 1,3-dibutoxy-2-propanol (2a) was synthesized by the reaction of n-butanol and 1,3dichloro-2-propanol in the presence of sodium metal. The reaction of $\mathbf{2 a}$ with phosphorus trichloride $\left(\mathrm{PCl}_{3}\right)$ at room temperature led to bis(1,3-dibutoxypropan-2-yl) phosphite (3a) with $78 \%$ yield. After purification, 3a was oxidised by $\mathrm{I}_{2}$ in pyridine-water mixture with ratio of 9:1 to form bis(1,3-dibutoxypropan-2-yl) phosphoric acid (BiDiBOPP, 4a) (Scheme 1). 
The cationic exchangers were synthesized by using the same procedure as for BiDiBOPP except for the synthesis of bis(undecan-6-yl) phosphoric acid (4d) (Table 1). Indeed, the corresponding alcohol $\mathbf{2 d}$ used for the synthesis of $\mathbf{4 d}$ was synthesized by the reduction of undecan-6-on with lithium aluminium hydride $\mathrm{LiAlH}_{4}$ at $0{ }^{\circ} \mathrm{C}$ in anhydrous $\mathrm{THF}$ according to the following reaction:

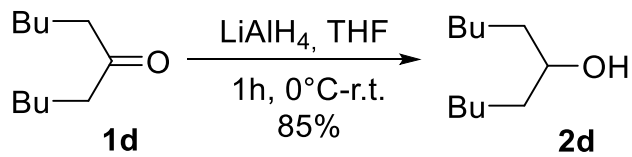

The reaction yields are reported in Table 2 .

The purities of the extractants synthesized in this work varied between $90 \%$ and 95\% (Table 3). They were determined by ${ }^{1} \mathrm{H},{ }^{13} \mathrm{C},{ }^{31} \mathrm{P}$ NMR spectroscopy, molecular mass spectroscopy (MS) and electrospray ionisation molecular mass spectroscopy (ESI-MS). For a sake of comparison, the purities were also determined by ${ }^{31} \mathrm{P}$ NMR. The ${ }^{31} \mathrm{P}$ NMR spectra of UPA and EHPA showed the presence of an impurity characterized by peaks located at $-14 \mathrm{ppm}$ and -13 ppm, respectively, attributed to the compounds reported in Table 4 [9]. The presence of such an impurity in UPA was confirmed by molecular mass-spectrometry.

The ${ }^{31} \mathrm{P}$ NMR spectra of the synthesized extractants also showed the presence of two peaks located at 0.5 and $20 \mathrm{ppm}$ corresponding to phosphorus impurities whose the total concentration was estimated to be lower than $5 \%$. This range of chemical shifts can be attributed to phosphonates (5-30 ppm), phosphine oxides (20-50 ppm) and phosphoric acid esters (0-15 ppm). Molecular mass-spectrometry analyses confirmed the presence of phosphoric acid and phosphonate esters whereas no trace of phosphine oxide was observed.

Impurities analyses showed that Cyanex ${ }^{\circledR} 272$ contained $11 \%$ phosphine oxide and $4.6 \%$ impurities bearing an acid functional group. Cyanex® 301 contained 10\% phosphine oxide whereas D2EHPA and Ionquest ${ }^{\circledR} 801$ contained only $1 \%$ and 3\% acids and/or esters as impurities [10].

Given that phosphine oxide is not a Brønsted acid and the concentrations of acid impurities are low, it was considered that the presence of these impurities did not significantly impact the values of the dissociation constants and the aggregation constants of the extractants determined by potentiometric measurements and Vapour Pressure Osmometry (VPO).

\section{2. $\quad$ pKa measurements}


D2EHPA (Sigma Aldrich, purity 97\%), Cyanex 272 (Solvay, purity=85\%), Cyanex 301 (Solvay, purity 90\%), Ionquest 801 (Solvay, purity 96\%) were used as delivered. Potassium chloride, ethanol, 2-propanol and other reagents were of analytical reagent grade.

The values of $\mathrm{pK}_{\mathrm{a}}$ in water/2-propanol mixtures were determined by potentiometric titrations with a glass electrode (Metrohm ${ }^{\circledR} 913$ ) at $25^{\circ} \mathrm{C}$ under nitrogen atmosphere (inert conditions). It was not possible to use water-ethanol mixtures due to solubility issues of the extracting agents synthesized in the present work. During the potentiometric titrations, the ionic strength of the water/propan-2-ol mixtures was kept constant at 0.1 mol. $\mathrm{L}^{-1}$ by using $\mathrm{KCl}$.

The electrode calibration was performed in buffer solutions containing different concentrations of 2-propanol in water according to the procedure described by Wilson et al. and Mussini et al. $[11,12]$. As the literature reported only buffer solutions in water/ethanol mixtures, it was assumed that $\mathrm{pH}$ values of the buffer solutions in water/2-propanol mixtures were the same as those in water/ethanol solutions reported in Table 5. Such an assumption relies on the fact that the chemicals structures of ethanol and 2-propanol are similar, the same types of interactions occurs in water/ethanol and water/2-propanol mixtures and these solvents exhibit similar values of dielectric constants (20.2 and 25.2 at $20{ }^{\circ} \mathrm{C}$ for 2-propanol and ethanol, respectively) and the same dipolar moments (1.69 D). This assumption was checked by determining the $\mathrm{pK}_{\mathrm{a}}$ of D2EHPA in water-ethanol and water-2-propanol mixtures by potentiometric measurement assuming that water/2-propanol buffer solutions have the same $\mathrm{pH}$ as water/ethanol buffer solutions reported in Table 5. Similar values of $\mathrm{pK}_{\mathrm{a}}$ of D2EHPA in water were deduced from potentiometric measurements in water/ethanol and water/2-propanol media, i.e $\mathrm{pK}_{\mathrm{a}}=2.3$ and 2.6, respectively. Although a difference is observed between both $\mathrm{pK}_{\mathrm{a}}$ values, it has been considered in the present paper that the difference is sufficiently small given the large discrepancies of $\mathrm{pK}_{\mathrm{a}}$ reported in the literature [See supporting information of ref. 3].

\subsection{Measurement of phoshorus content in aqueous phases}

Solubility of organophosphorus compounds in aqueous phase was determined by the colorimetric method after digestion with concentrated sulphuric acid as reported by Biswas et al. [14]. In this method, orthophosphate was formed, during the digestion of the organophosphorus compounds. Orthophosphate concentration was estimated by the molybdenum-blue method at $830 \mathrm{~nm}$ [15].

\section{4. $\quad$ Vapor Pressure Osmometry measurements}


The organic solutions of tri-n-octylamine (TOA, Aldrich, purity=99\%) and organophosphorus acids diluted in $n$-heptane were prepared by weight so that extractant concentrations were comprised between 0.05 and $0.5 \mathrm{~mol} \mathrm{~kg}^{-1}$. Vapor Pressure Osmometry (VPO) measurements were carried out at $25{ }^{\circ} \mathrm{C}$ using a Knauer K-7000 Vapour Pressure Osmometer.

Prior to VPO measurements, the thermocouple head was cleaned thoroughly, and the osmometer was calibrated with TOA diluted in n-heptane. Calibration was performed using TOA diluted in n-heptane because TOA was expected to be monomeric in n-heptane in the concentration range of interest.

The difference of resistance $(\Delta \mathrm{R})$ was measured as a function of the concentration for both standard and organophosphorus acids. The measured property $\Delta \mathrm{R}$ may be expressed as a function of the total extractant concentration $\mathrm{m}_{\mathrm{HL}}^{0}$ as:

$$
\Delta \mathrm{R}=\mathrm{k}_{\mathrm{cal}} \mathrm{m}_{\overline{\mathrm{HL}}}^{0}
$$

where $\mathrm{k}_{\mathrm{cal}}$ is the calibration constant, which can be obtained by measuring $\Delta \mathrm{R}$ for different TOA solutions since TOA exists only as monomers in n-heptane in the range of investigated concentrations. In order to obtain reliable $\Delta \mathrm{R}$ values, the drop size was kept as constant as possible and equal in both thermistors, and the measurements were performed by reading $\Delta \mathrm{R}$ five minutes after placing the drops on the thermistors. Five readings were recorded for each sample and the average value was used in all calculations. In this manner, the precision of $\Delta \mathrm{R}$ were maintained below $2 \%$. The calibration constant deduced from VPO measurements with TOA in n-heptane at $25^{\circ} \mathrm{C}$ was $\mathrm{k}_{\mathrm{cal}}=2015,5 \Omega \cdot \mathrm{kg} \cdot \mathrm{mol}^{-1}$.

\section{Results and Discussions}

\section{1. $\quad$ Acid dissociation constants}

The low water solubility of long chain organophosphorus acids prevents the direct determination of $\mathrm{pK}_{\mathrm{a}}$ in water by potentiometric measurements. Therefore, the acid dissociation constants of the organophosphorus acids were determined by potentiometry in water/propan-2-ol mixtures. The $\mathrm{pK}_{\mathrm{a}}$ values of the organophosphorus compounds in water/propan-2-ol mixtures were determined by using the Gran equation:

$$
V_{b} \cdot 10^{-p H}=\frac{\gamma_{H L}}{\gamma_{L^{-}}} K_{a}\left(V_{e}-V_{b}\right)
$$

where $V_{b}$ is the volume of sodium hydroxide used for the titrations, $\gamma_{H L}$ and $\gamma_{L^{-}}$are the activity coefficients of the protonated form (HL) and the dissociated form ( $\left.\mathrm{L}^{-}\right)$of the 
organophosphorus compounds, respectively. $K_{a}$ denotes the acid dissociation constant and $V_{e}$ is the equivalence volume. It is expected that the ratio $\frac{\gamma_{H A}}{\gamma_{A^{-}}}=1$ at constant ionic strength.

Acid dissociation can be described by the following equilibrium [16]:

$$
\mathrm{HL}+\mathrm{H}_{2} \mathrm{O} \rightleftharpoons\left[\mathrm{L} \cdots \mathrm{H} \cdots \mathrm{H}_{2} \mathrm{O}\right]^{\neq} \rightleftharpoons \mathrm{L}^{-}+\mathrm{H}_{3} \mathrm{O}^{+}
$$

where $\left[\mathrm{L} \cdots \mathrm{H} \cdots \mathrm{H}_{2} \mathrm{O}\right]^{\neq}$is an activated complex.

The solvent effect of ion-ion, ion-dipole and dipole-dipole interactions can be estimated by means of the Kirkwood equation $[17,18]$ :

$$
p K_{a}=p K_{a}^{0}+\frac{1}{2,303}\left[\frac{e^{2}}{2 k T}\left(\frac{1}{r_{L^{-}}}+\frac{1}{r_{H_{3} O^{+}}}\right)+\frac{3}{4 k T}\left(\frac{\mu_{\neq}^{2}}{r_{\neq}^{3}}-\frac{\mu_{H_{L}}^{2}}{r_{H L}^{3}}-\frac{\mu_{H_{2} O}^{2}}{r_{H_{2} O}^{3}}\right)\right] \frac{1}{\varepsilon}
$$

where $\varepsilon$ is the dielectric constant of the solvent, $p K_{a}^{0}$ is the $p K_{a}$ value at infinite dielectric constant, e is equal to $1.610^{-19} \mathrm{C}$, $\mathrm{k}$ is the Boltzmann constant $\left(1.3810^{-23} \mathrm{~m}^{2} \mathrm{~kg} \mathrm{~s}^{-2} \mathrm{~K}^{-1}\right)$, $\mathrm{T}$ is the temperature in Kelvin, $\mathrm{r}$ is the radius of charges species (in $\mathrm{m}$ ), $\mu$ is the dipole moment (in D).

This equation shows a linear relationship between $\mathrm{pK}_{\mathrm{a}}$ values and $1 / \varepsilon$. Such a relationship is interesting as it allows the determination by extrapolation of $\mathrm{pK}_{\mathrm{a}}$ of compounds poorly soluble in water by using solvent mixtures in which the compound is soluble. In the present case, mixtures of water and propan-2-ol was utilized since the synthesized and commercial organophosphorus compounds exhibit a very low solubility in water and high solubility in water/propan-2-ol mixtures.

In order to calculate the $\mathrm{pK}_{\mathrm{a}}$ values of the organophosphorus compounds in water, their $\mathrm{pK}_{\mathrm{a}}$ in several mixtures of water and propan-2-ol have been determined by potentiometric measurements and the Gran method [Eq. (2)]. Figure 1 demonstrates the validity of Eq. (4).

In Figure 1, the values of the dielectric constants of the water/propan-2-ol mixtures have been calculated by using Eq. (5) deduced from the Redlish-Kister equation [19] and the data reported by Hasted [20]:

$\varepsilon_{\mathrm{w} / \text { prop }}=\mathrm{x}_{\text {prop }} \varepsilon_{\text {prop }}+\left(1-\mathrm{x}_{\text {prop }}\right) \varepsilon_{\mathrm{w}}\left[34.809\left(1-2 \mathrm{x}_{\text {prop }}\right)^{4}+7.0591\left(1-2 \mathrm{x}_{\text {prop }}\right)^{3}+3.3614\left(1-2 \mathrm{x}_{\text {prop }}\right)^{2}-54.456(1-\right.$

$\left.\left.2 \mathrm{x}_{\text {prop}}\right)-94.878\right]$

where $\varepsilon_{\mathrm{w} / \text { prop }}, \varepsilon_{\mathrm{w}}$ and $\varepsilon_{\text {prop }}$ are the dielectric constants of the water-ethanol mixture, water $\left(\varepsilon_{\mathrm{w}}=78.5\right)$ and 2-propanol $\left(\varepsilon_{\mathrm{w}}=18.6\right)$, respectively, and $\mathrm{x}_{\mathrm{prop}}$ denotes the mole fraction of 2propanol in the mixture. 
Table 6 gathers the $\mathrm{pK}_{\mathrm{a}}$ values of the organophosphorus acids in aqueous solution of 1 mol.L $\mathrm{L}^{-1}$ $\mathrm{KCl}$ deduced by extrapolation at $\varepsilon_{\mathrm{r}}=78.5$ (dielectric constant of water at $25{ }^{\circ} \mathrm{C}$ ) with the linear relationship found in Figure 1.

The $\mathrm{pK}_{\mathrm{a}}$ values determined in the present work for the commercial extractants are in accordance with those reported in the literature (Table 6). The difference in $\mathrm{pK}_{\mathrm{a}}$ is likely due to the difference in ionic strength and experimental methods used to determine the $\mathrm{pK}_{\mathrm{a}}$ (examination of $\mathrm{pK}_{\mathrm{a}}$ data from the literature shows discrepancies depending on the methods used for determining $\mathrm{pK}_{\mathrm{a}}$ of hydrophobic compounds [21]).

It can be observed in Table 6 that an increase of the number of oxygen atoms in the hydrophobic chains and an increase of the number of $\mathrm{P}-\mathrm{O}$ bonds in the structure of the organophosphorus acids decrease $\mathrm{pK}_{\mathrm{a}}$ values likely due to attractive inductive effects, which are responsible for an increase of $\mathrm{O}-\mathrm{H}$ bond polarization. Such an observation was also reported by $\mathrm{Fu}$ et al. and Binghua et al. [22, 23]. Furthermore, there is no influence of the nature of the hydrophobic chains on the $\mathrm{pK}_{\mathrm{a}}$ values, excepting for BiDiBOPP and IPA. In the latter cases, branching of the hydrophobic chains is responsible for a slight increase of $\mathrm{pK}_{\mathrm{a}}$ as it has ever been reported by Martinez et al. [24]. Furthermore, the acidity increases when an oxygen atom is replaced by a sulphur atom because of an increase of the proton lability in the presence of sulphur atom resulting from the difference in electronegativity [25].

\subsection{Aggregation constants}

Figure 2 shows $\Delta \mathrm{R}$ deduced from VPO measurements as a function of the total concentration of the organophosphorus acids at $25^{\circ} \mathrm{C}$ [Eq. (1)]. The average molecular weight in g.mol ${ }^{-1}$ of the extractants can be deduced by the following equation:

$$
\bar{M}=\frac{k_{c a l}}{k_{\text {extractant }}}
$$

where $\mathrm{k}_{\mathrm{cal}}$ is the calibration constant $\left(\mathrm{k}_{\mathrm{cal}}=2015,5 \Omega \cdot \mathrm{kg} \cdot \mathrm{mol}^{-1}\right.$ for TOA diluted in $\mathrm{n}$-heptane $)$ and $\mathrm{k}_{\text {extractant }}$ in $\Omega \cdot \mathrm{kg}_{\mathrm{g}} \mathrm{g}^{-1}$ is the slope of the linear relationship $\Delta \mathrm{R}=\mathrm{k}_{\text {extractant }} \mathrm{m}_{\mathrm{HL}}^{0}$ plotted in Figure 2 where $\mathrm{m}_{\overline{\mathrm{HL}}}^{0}$ is the total concentration of organophosphorus acid in n-heptane. The values of $\mathrm{k}_{\text {extractant }}$ and $\bar{M}$ are given in Table 7 as well as the average number of aggregates of the organophosphorus acids, which were calculated by using Eq. (7).

$$
\bar{n}=\frac{\breve{M}}{M_{\text {monomer }}}
$$

where $\mathrm{M}_{\text {monomer }}$ is the molecular weight of the monomeric forms of organophosphorus acids. 
Table 7 shows that the synthesized organophosphorus acids exhibit a weak tendency to form aggregates under the present experimental conditions. However, the organophosphorus acids seem to exist as dimers and they could eventually form trimers.

The aggregation of the organophosphorus acid compounds can be expressed as:

$$
\begin{aligned}
& 2 \overline{H L} \rightleftharpoons(\overline{H L})_{2} \\
& 3 \overline{H L} \rightleftharpoons(\overline{H L})_{3}
\end{aligned}
$$

Assuming ideal behavior of organophosphorus acids, the stoichiometric constant $\mathrm{K}_{2}$ and $\mathrm{K}_{3}$ for the dimerization and the trimerisation equilibria, respectively, can be written as:

and

$$
\begin{gathered}
K_{2}=\frac{m_{(\overline{H L})_{2}}}{m_{(\overline{H L})}^{2}} \\
K_{3}=\frac{m_{(\overline{H L})_{3}}}{m_{(\overline{H L})}^{3}}
\end{gathered}
$$

The total concentration of the monomeric form of organophosphorus acid $\left(\mathrm{m}_{\overline{\mathrm{HL}}}^{0}\right)$ can be expressed as:

$$
\mathrm{m}_{\overline{\mathrm{HL}}}^{0}=\mathrm{m}_{\overline{\mathrm{HL}}}+2 \mathrm{~K}_{2} \mathrm{~m}_{\overline{\mathrm{HL}}}^{2}+3 \mathrm{~K}_{3} \mathrm{~m}_{\overline{\mathrm{HL}}}^{3}
$$

The apparent concentration of organophosphorus acid $\left(\mathrm{m}_{\overline{\mathrm{HL}}}^{\mathrm{app}}\right)$, i.e. the total concentration of monomeric and associated organophosphorus acids, is defined as:

$$
\mathrm{m}_{\overline{\mathrm{HL}}}^{\mathrm{app}}=\mathrm{m}_{\overline{\mathrm{HL}}}+\mathrm{K}_{2} \mathrm{~m}_{\overline{\mathrm{HL}}}^{2}+\mathrm{K}_{3} \mathrm{~m}_{\overline{\mathrm{HL}}}^{3}
$$

The following equation is deduced from Eq. (13);

$$
\frac{\mathrm{dm}_{\overline{\mathrm{HL}}}^{\mathrm{app}}}{\mathrm{dm}_{\overline{\mathrm{HL}}}}=1+2 \mathrm{~K}_{2} \mathrm{~m}_{\overline{\mathrm{HL}}}+3 \mathrm{~K}_{3} \mathrm{~m}_{\overline{\mathrm{HL}}}^{2}
$$

By combining Eqs. (12) and (14), the following equation can be written:

$$
\frac{d m_{\overline{H L}}^{a p p}}{d m_{\overline{H L}}}=1+2 K_{2} m_{\overline{H L}}+3 K_{3} m_{\overline{H L}}^{2}=\frac{\mathrm{m}_{\overline{\mathrm{HL}}}^{0}}{\mathrm{~m}_{\overline{\mathrm{HL}}}}
$$

The average number of aggregates $\bar{n}$ given in Eq. 8 can be rewritten as: 


$$
\bar{n}=\frac{m \frac{0}{H L}}{m \frac{a p p}{H L}}
$$

Therefore, Eq. (15) can be rewritten as follows:

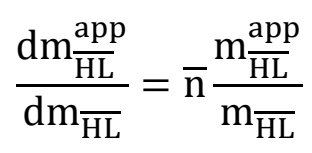

The following expression deduced from Eq. (17) can be used to calculate the concentration of the monomeric form of the organophosphorus acid $\left(m_{\overline{H L}}\right)$ :

$$
\ln \left(m_{\overline{H L}}\right)-\ln \left(\mathrm{m}_{\overline{\mathrm{HL}}}^{0}\right)=\int_{\mathrm{m}_{\overline{\mathrm{HL}}}^{0}}^{m_{\overline{H L}}^{a p p}} \frac{1}{\bar{n}} d\left(\ln \left(m_{\overline{H L}}^{a p p}\right)\right)
$$

with

$$
\begin{gathered}
\mathrm{m} \frac{0}{\mathrm{HL}}=\frac{\mathrm{w}(\text { extractant }) \cdot 1000}{\mathrm{w}(\text { solvent }) \cdot \mathrm{MW}(\text { extractant })} \\
m_{\frac{a p p}{H L}}=\frac{\Delta R}{\mathrm{k}_{c a l}}
\end{gathered}
$$

where $\mathrm{w}($ extractant $)$ and $\mathrm{w}($ solvent $)$ are the weight of extractant and solvent, respectively, and $\mathrm{MW}$ is the molecular weight of the extractant in $\mathrm{g} \cdot \mathrm{mol}^{-1} . \Delta \mathrm{R}$ and $\mathrm{k}_{\mathrm{cal}}$ denote the difference in resistance and the calibration constant in $\Omega \cdot \mathrm{kg} \cdot \mathrm{mol}^{-1}$ measured during VPO experiments , respectively.

Finally, the dimerization and trimerisation constants can be calculated by plotting the following equations:

$$
\begin{aligned}
& \frac{\frac{m_{\overline{\mathrm{HL}}}^{0}}{m_{\overline{H L}}}-1}{m_{\overline{H L}}}=2 \mathrm{~K}_{2}+3 \mathrm{~K}_{3} m_{\overline{H L}} \\
& \frac{\frac{m_{\overline{H L}}^{a p p}}{m_{\overline{H L}}}-1}{m_{\overline{H L}}}=\mathrm{K}_{2}+\mathrm{K}_{3} m_{\overline{H L}}
\end{aligned}
$$

The corresponding values of $\mathrm{K}_{2}$ and $\mathrm{K}_{3}$ are gathered in Table 7. These values have been used to calculate the average number of aggregation $(\bar{n})$ as a function of extractant concentration 
(Figure 3). A good agreement has been found between calculated and experimental values of $\bar{n}$.

Aggregation diagrams of the extractants as a function of the total concentration of extractants diluted in $n$-heptane have been calculated by using $K_{2}$ and $K_{3}$ (Figure 4). No trimer was observed in the extraction solvent containing UPA and EHPA while dimers and trimers exist in BiDiBOPP and IPA diluted in n-heptane. The dimerization and trimerization constants are very low compared to those determined by Buch et al. for D2EHPA in n-heptane $\left(K_{2}=\right.$ $\left.115, K_{3}=3286\right)$ likely because of the high steric hindrance of the organophosphorus acids synthesized in the present work, which may not favor hydrogen bonds and may destabilize the aggregates [27].

\subsection{Partition coefficient}

The partition coefficients of the organophosphorus compounds $(\mathrm{P})$ between 1 mol.L $\mathrm{L}^{-1} \mathrm{HCl}$ and HL diluted in n-dodecane is defined by the following equation:

$$
\mathrm{HL} \rightleftharpoons \overline{\mathrm{HL}} \mathrm{P}=\frac{[\overline{\mathrm{HL}}]}{[\mathrm{HL}]}
$$

where $\overline{[\overline{\mathrm{HL}}]}$ and $[\mathrm{HL}]$ are the concentrations of the monomeric form of the organophosphorus acid in the organic phase and in the aqueous phase, respectively.

[HL] can be expressed as:

$$
[H L]=\frac{S_{H L}}{\left(1+\frac{K_{a}}{\left[H^{+}\right]}\right)}
$$

where $\mathrm{S}_{\mathrm{HL}}$ is the solubility of the organophosphorus acid in the aqueous phase determined by colorimetric titration.

$[\overline{H L}]$ can be calculated by solving the following equation:

$$
[\overline{\mathrm{HL}}]_{0}=[\overline{\mathrm{HL}}]+2\left[(\overline{\mathrm{HL}})_{2}\right]+3\left[(\overline{\mathrm{HL}})_{3}\right]=[\overline{\mathrm{HL}}]+2 \mathrm{~K}_{2}[(\overline{\mathrm{HL}})]^{2}+3 \mathrm{~K}_{3}[(\overline{\mathrm{HL}})]^{3}
$$

where $[\overline{\mathrm{HL}}]_{0}, \mathrm{~K}_{2}$ and $\mathrm{K}_{3}$ are the initial concentration of the organophosphorus acid in the organic phase, the dimerization constant and the trimerization constant, respectively.

Table 8 gathers the partition coefficients of the monomeric form of the organophosphorus compounds calculated by using Eqs. (22) and (23). The partition coefficients of the monomeric form of the synthesized extractants are between 10 and 100 times greater than 
those obtained for commercial extractants. The hydrophobicity of the synthesized extractants is obviously higher since the length of the hydrocarbon chains are longer.

\section{Conclusion}

The chemical structure of the organophosphorus extractants influences the acidic properties and the aggregation behavior. The values of $\mathrm{pK}_{\mathrm{a}}$ are strongly affected by the presence of oxygen atoms in the alkyls chains. It appears that $\mathrm{pKa}$ values increase in the following order: phosphoric acid $<$ phosphonic acid $<$ phosphonic acid and the presence of sulphur increases the acidity of the molecules. Conversely, there is no significant influence of the hydrophobilicty of the extractants on their acidity strength. Agregation characterization shows that bis(undécan-6-yl) phosphoric acid (UPA) exhibits a weak association while the two isomers, bis(1,3-dibutoxypropan-2-yl) phosphoric acid (BiDiBOPP) and bis(1,3diisobutoxypropan-2-yl) phosphoric acid (IPA) form more dimers and trimers. All syhnthesized extractants exhibit very low aggregation constants compared to D2EHPA likely because of the high steric hindrance, which may not favor hydrogen bonds and may destabilize the aggregates.

\section{REFERENCES}

1. A. CHAGNES, FUNDAMENTALS IN ELECTROCHEMISTRY AND HYDROMETALlurgy, IN: A. Chagnes, J. SWiATOWSKA, EDITEURS, LiTHIUM PROCESS CHEMISTRY: RESOURCES, EXTRACTIONS, BATTERIES AND RECYCLING. 1ST ED. AMSTERDAM: ELSEVIER, 2015 (ISBN: 978-0-12-801417-2). P. 41-80.

2. A. Chagnes, G. Cote, SÉparation du cobalt et du nickel à l'aide du CYANEX® 272 PAR EXTRACTION LIQUIDE-LIQUIDE, L'ACTUALITÉ CHIMIQUE 346 (2010) 29-34.

3. K. Omelchuk, P. Szczepański, A. Shrotre, M. Haddad, A. Chagnes, Effects of Structural Changes of New Organophosphorus Cationic Exchangers on a Solvent Extraction of Cobalt, Nickel and Manganese from Acidic Chloride Media, RSC Adv. 7 (10) (2016) 5660-68.

4. S. D. Flett, Cobalt-Nickel Separation in Hydrometallurgy: A REVIEW, CHEMISTRY FOR SustainABLE DEVELOPMENT 12 (2004) 81-91.

5. D. Beltrami, G. Cote, H. Mokhtari, B. Courtaud, B. A. Moyer, A. Chagnes, A review on the recovery of uranium(VI) from wet phosphoric acid by solvent extraction processes, Chemical Reviews 114 (24) (2014) 12002-12023. 
6. D. Beltrami, A. Chagnes, M. Haddad, H. Laureano, H. Mokhtari, B. COURTAud, S. Juge, G. COTE, DEVElOPMENT OF NEW CATIONIC EXCHANGERS FOR THE RECOVERY OF URANIUM (VI) FROM WET PHOSPHORIC ACID, SEPARATION SCIENCE AND TECHNOLOGY 48 (2013) 480-486.

7. D. Beltrami, G. Cote, H. Mokhtari, B. Courtaud, A. Chagnes, Modelling of the extraction of uranium (VI) from concentrated phosphoric acid by synergistic mixtures of bis-(2-ethylhexyl)-phosphoric acid and tri-n-octylphosphine oxide, Hydrometallurgy 129-130 (2012) 118-125.

8. G. J-P. Deblonde, A. Chagnes, M.-A. Roux, V. Weigel, G. Cote, EXTRACTION OF NB(V) BY QUATERNARY AMMONIUM-BASED SOLVENTS: TOWARD ORGANIC HEXANIOBATE SYSTEMS, DALTON TRANSACTIONS 45 (2016) 19351-19360.

9. J.C. Tebby, Handbook of Phosphorus-31 Nuclear Magnetic Resonance DataCRC Press, $1^{\text {st }}$ edition (1991).

10. R.K. Biswas, M.A. Habib, M.G.K. Mondal, Kinetics and Mechanism of Stripping of Mn(II)D2EHPA Complex by Sulphuric Acid Solution, Hydrometallurgy 80 (3) (2005) 186-195.

11. G.S. Wilson, R.P. Buck, S. Rondinini, A.K. Covington, F.G.K. Baucke, C.M. Brett, K.W. Pratt, Measurement of $\mathrm{pH}$. Definition, standards, and procedures, Pure and Appl. Chem. 74 (11) (2002) 2169-2200.

12. P.R. Mussini, T. MUSSINI, S. RONDININI, REFERENCE VALUE STANDARDS AND PRIMARY STANDARDS FOR PH MEASUREMENTS IN $\mathrm{D}_{2} \mathrm{O}$ AND AQUEOUS ORGANIC SOLVENT MIXTURES: NEW ACCESSIONS AND ASSESSMENTS, PURE AND APPLIED CHEMISTRY 69 (5) (1997) 1007-1014.

13. D.D. Perrin, B. Dempsey, Buffers for $\mathrm{pH}$ and metal ion control, Springer Editor (1974).

14. R.K. Biswas, M.A. Habib, H.P. Singha, Colorimetric Estimation AND SOME PHYSICOCHEMICAL PROPERTIES OF PURIFIED CYANEX 272, HYDROMETALLURGY 76 (1-2) (2005) 97-104.

15. A.I. Vogel, A TEXT BoOK OF QUANTITATIVE INORGANIC ANALYSIS, $3^{\text {RD }}$ EDITION, LONGMANS, LONDON (1961) P. 810.

16. G.T. Castro, O.S. Giordano, S.E. Blanco, Determination of the pKa of HydroxyBenzophenones in Ethanol-water Mixtures. Solvent Effects, Journal of Molecular Structure: Theochem 626 (1-3) (2003) 167-78.

17. J.G. Kirkwood, Theory of Solutions of Molecules Containing Widely Separated Charges with Special Application to Zwitterions, The Journal of Chemical Physics 2 (7) (1934) 351-61.

18. K.J. Laidler, K.J, Chemical Kinetics, $3^{\text {rd }}$ edition, New York: Harper Collins (1987).

19. C. Mialkowski, A. Chagnes, B. Carre, P. Willmann, D. Lemordant, EXCESS THERMODYNAMIC PROPERTIES OF BINARY LIQUID MIXTURES CONTAINING DIMETHYL CARBONATE AND $\gamma$-BUTYROLACTONE, THE JOURNAL OF CHEMICAL THERMODYNAMICS 34 (11) (2002) 1845-1854.

20. J. B. Hasted, Water: A Comprehensive Treatise 2 (1973) 405. 
21. Z. Kolarik, REview: Dissociation, SElF-AsSOCIATION, AND PARTITION OF MONOACIDIC ORGANOPHOSPHORUS EXTRACTANTS, SOLVENT EXTRACTION AND ION EXCHANGE, 28 (6) (2010) 707-763.

22. F. Xun, Z. Hu, Y. Liu, J. A. Golding, Extraction of sodium in bis(2,4,4trimethylpentyl) phosphoric acid Cyanex 272. Basic constants and extraction equilibria, Solvent Extraction and Ion Exchange 8 (4-5) (1990) 573-595.

23. Y. Binghua, Y. Nagaosa, M. Satake, A. Nomura, K. Horita, Solvent extraction of metal ions and separation of nickel(II) from other metal ions by organophosphorus acids, Solvent Extraction and Ion Exchange 14 (5) (1996) 849-870.

24. M. Martinez, N. Miralles, A. Sastre, E. Bosch. Dissociation Constants of Organophosphinic Acid Compounds.” Talanta 40 (9) (1993) 1339-1343.

25. F. Xun, X. Yahong, X. Shuyun, Z. Shaona, H. Zhengshui, Study on the thiophosphinic extractants - I. The basic properties of the thiophosphinic extractants and the phase behavior in their saponified systhems, Solvent Extraction and Ion Exchange 20 (3) (2002) 331-344.

26. Y. Binghua, Y. Nagaosa, M. Satake, A. Nomura, K. Horita, Solvent extraction of metal ions and separation of nickel(II) from other metal ions by organophosphorus acids, Solvent Extraction and Ion Exchange 14 (5) (1996) 849-870.

27. A. Buch, M. Stambouli, D. Pareau, G. Durand, Solvent extraction of NICKEL(II) BY MIXTURE OF 2-ethylhexanal oxime and bis(2-ethylhexyl) phosphoric acid, Solvent Extraction and Ion Exchange 20 (1) (2002) 49-66. 


\section{TABLE}

TABLE 1: Organophosphorus compounds studied in the present work.

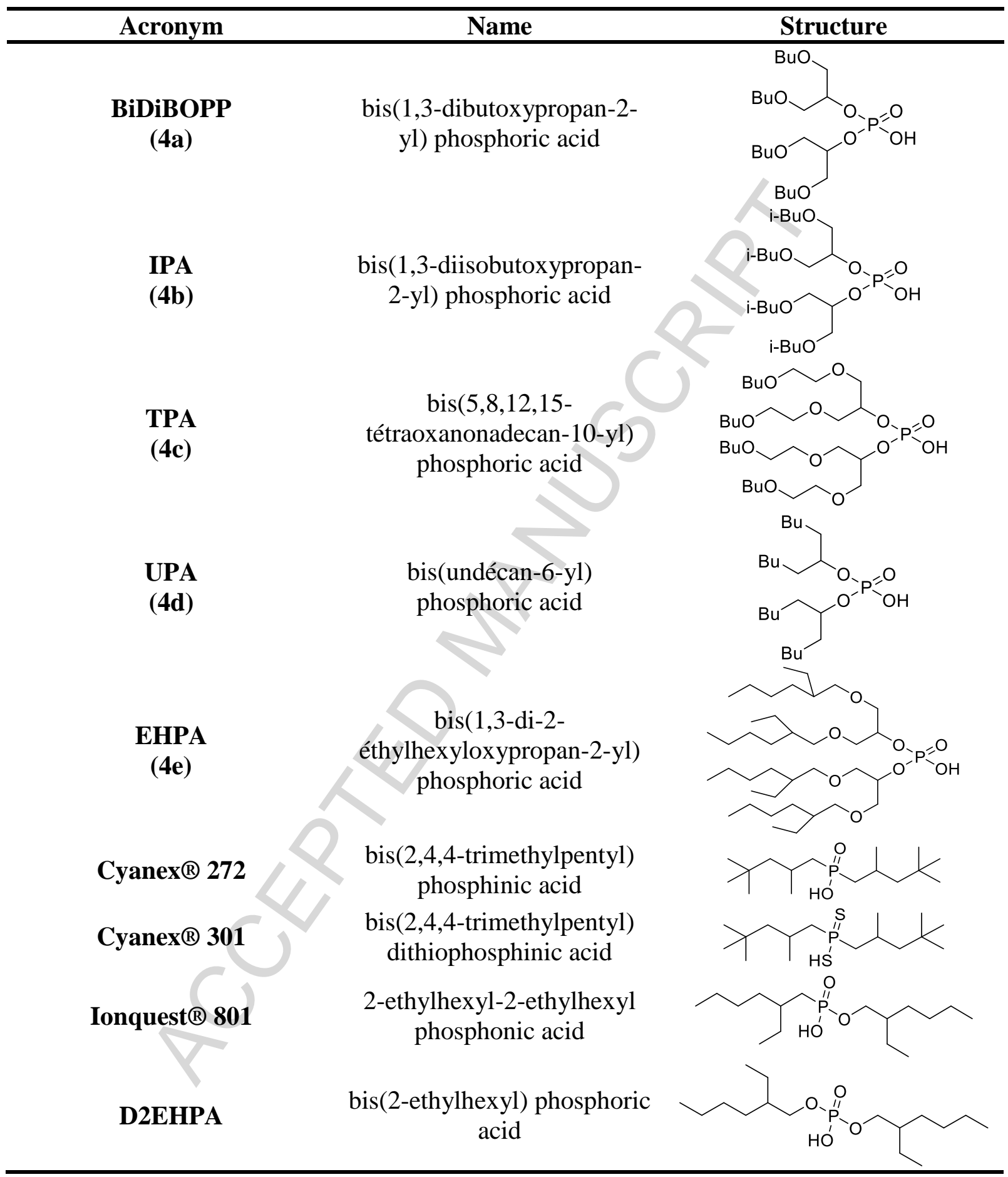


Table 2: Reaction yields for the synthesis of new extractants.

\begin{tabular}{ccc}
\hline$\#$ & Name & $\begin{array}{c}\text { Yield } \\
\text { \% }\end{array}$ \\
\hline $\mathbf{4 a}$ & $\begin{array}{c}\text { bis(1,3-dibutoxypropan-2-yl) phosphoric } \\
\text { acid (BiDiBOPP) }\end{array}$ & 78 \\
$\mathbf{4 b}$ & $\begin{array}{c}\text { bis(1,3-diisobutoxypropan-2-yl) phosphoric } \\
\text { acid (IPA) }\end{array}$ & 90 \\
$\mathbf{4 c}$ & $\begin{array}{c}\text { bis(5,8,12,15-tetraoxanonadecan-10-yl) } \\
\text { phosphoric acid (TPA) }\end{array}$ & 84 \\
$\mathbf{4 d}$ & $\begin{array}{c}\text { bis(undecan-6-yl)phosphoric acid (UPA) } \\
\text { bis(1,3-di-2-ethylhexyloxypropan-2-yl) } \\
\text { 4e }\end{array}$ & 92 \\
\hline
\end{tabular}

Table 3: Purities (\%P) of the extractants synthesized in the present work determined by molecular Mass Spectroscopy (MS), Ionization Electrospray molecular Mass Spectroscopy (ESI-MS), ${ }^{31} \mathrm{P}$ NMR, ${ }^{13} \mathrm{C}$ NMR and ${ }^{1} \mathrm{H}$ NMR spectroscopy.

\begin{tabular}{|c|c|c|c|c|c|c|c|}
\hline Extractants & $\begin{array}{c}\text { MW } \\
(\text { g.mol } \\
\text { (1) }\end{array}$ & $\begin{array}{c}\% \mathbf{P} \\
(\mathbf{M S})\end{array}$ & $\begin{array}{c}\% \mathbf{P} \\
\text { (ESI- } \\
\text { MS) } \\
\end{array}$ & $\begin{array}{c}\% \mathbf{P} \\
\left({ }^{31} \mathbf{P}\right. \\
\text { NMR }) \\
\end{array}$ & $\begin{array}{c}\% \mathbf{P} \\
\left({ }^{1} \mathbf{H}\right. \\
\text { NMR }) \\
\end{array}$ & $\begin{array}{c}\% P\left({ }^{13} \mathrm{C}\right. \\
\text { NMR })\end{array}$ & $\begin{array}{l}\text { Estimated } \\
\text { purity, \% }\end{array}$ \\
\hline IPA & 470 & 99 & 99 & 97 & 94 & 99 & 94 \\
\hline UPA & 406 & 99 & 99 & 94 & 92 & 99 & 92 \\
\hline TPA & 646 & 99 & 99 & 98 & 93 & 99 & 93 \\
\hline BiDiBOPP & 470 & 99 & 99 & 100 & 96 & 99 & 96 \\
\hline EHPA & 695 & 99 & 99 & 93 & 92 & 99 & 92 \\
\hline
\end{tabular}

Table 4: Impurities identified in UPA and EHPA.

\begin{tabular}{ccc}
\hline Extractants & Chemical shift (ppm) & Impurity structure \\
\hline UPA & -14 & $\left(\begin{array}{c}\mathrm{Bu} \\
\text { EHPA }\end{array}\right.$ \\
\hline
\end{tabular}


Table 5: Buffer solutions in water/ethanol mixtures for the determination of $\mathrm{pK}_{\mathrm{a}}$ values by potentiometric titration $[12,13]$.

\begin{tabular}{|c|c|c|c|}
\hline \multirow[b]{2}{*}{$\begin{array}{c}\text { Ethanol, } \\
\%(w / w)\end{array}$} & \multirow[b]{2}{*}{$\mathrm{pH}\left(25^{\circ} \mathrm{C}\right)$} & \multicolumn{2}{|c|}{ Buffer solutions } \\
\hline & & Compounds & $\begin{array}{c}\text { Concentration, } \\
\text { mol.kg }^{-1}\end{array}$ \\
\hline \multirow{4}{*}{40.0} & 4.973 & $\mathrm{KHPh}$ & 0.05 \\
\hline & 7.597 & $\begin{array}{c}\mathrm{KH}_{2} \mathrm{PO}_{4} \\
\mathrm{Na}_{2} \mathrm{HPO}_{4}\end{array}$ & $\begin{array}{l}0.025 \\
0.025\end{array}$ \\
\hline & \multirow{2}{*}{5.395} & HOAc & 0.05 \\
\hline & & $\mathrm{NaOAc}$ & 0.05 \\
\hline \multirow{6}{*}{52.0} & \multirow{2}{*}{2.79} & $\mathrm{NaCl}$ & 0.008840 \\
\hline & & $\mathrm{HCl}$ & 0.002210 \\
\hline & \multirow{2}{*}{5.40} & $\mathrm{NaCl}$ & 0.00553 \\
\hline & & $\mathrm{HOA}$ & 0.0221 \\
\hline & \multirow{2}{*}{6.92} & TEA & 0.00221 \\
\hline & & TEA-HCl & 0.00442 \\
\hline \multirow{7}{*}{73.4} & \multirow{3}{*}{2.88} & $\mathrm{NaCl}$ & 0.009352 \\
\hline & & $\mathrm{HC}$ & 0.002338 \\
\hline & & $\mathrm{NaCl}$ & 0.00585 \\
\hline & \multirow{4}{*}{6.75} & HOAc & 0.0234 \\
\hline & & $\mathrm{NaOAc}$ & 0.0117 \\
\hline & & TEA & 0.00234 \\
\hline & & TEA-HCl & 0.00468 \\
\hline \multirow{7}{*}{85.4} & \multirow{3}{*}{3.01} & $\mathrm{NaCl}$ & 0.009688 \\
\hline & & $\mathrm{HCl}$ & 0.002422 \\
\hline & & $\mathrm{NaCl}$ & 0.00605 \\
\hline & \multirow[t]{2}{*}{6.65} & HOAc & 0.0242 \\
\hline & & $\mathrm{NaOAc}$ & 0.0121 \\
\hline & \multirow{2}{*}{6.74} & TEA & 0.00242 \\
\hline & & TEA-HCl & 0.00484 \\
\hline
\end{tabular}


Table 6: Experimental $\mathrm{pK}_{\mathrm{a}}$ values of organophosphorus acids in aqueous solution of 1 mol. $\mathrm{L}^{-}$ ${ }^{1} \mathrm{KCl}$. ${ }^{\mathrm{a}}$ : $\mathrm{pK}_{\mathrm{a}}$ values from $[3,25,26],{ }^{\mathrm{b}}$ : this work.

\begin{tabular}{ccc}
\hline Extractants & $\mathbf{p K}_{\mathbf{a}}\left(\right.$ lit. $^{\mathbf{a}}$ & $\mathbf{p K}_{\mathbf{a}}(\mathbf{e x p} .)^{\mathbf{b}}$ \\
\hline $\begin{array}{c}\text { Cyanex}{ }^{\circledR} \\
\mathbf{3 0 1}\end{array}$ & 2,84 & 2.9 \\
$\begin{array}{c}\text { Cyanex } \\
\text { 272 }\end{array}$ & 3,73 & 4.2 \\
$\begin{array}{c}\text { Ionquest } \\
{ }^{\mathbf{2}}\end{array}$ & 3,30 & 3.0 \\
$\mathbf{8 0 1}$ & & \\
D2EHPA & 2,75 & 2.6 \\
Bidibopp & - & 2.4 \\
IPA & - & 2.5 \\
TPA & - & 2.3 \\
UPA & - & 3.5 \\
\hline
\end{tabular}

Table 7: Values of $\mathrm{K}_{\text {extractant }}$ in $\Omega . \mathrm{kg}_{\mathrm{g}} \mathrm{g}^{-1}$, average molecular weight $\bar{M}$ in g.mol ${ }^{-1}$, average aggregation number $\bar{n}$ of the extractants, dimerization constant $\left(\mathrm{K}_{2}\right)$ and trimerization constant $\left(\mathrm{K}_{3}\right)$ deduced by VPO.

\begin{tabular}{|c|c|c|c|c|c|}
\hline Extractant & $\begin{array}{l}\text { Kextractant, } \\
\text { Q.kg.g }^{-1}\end{array}$ & $\bar{M}, \mathrm{~g} \cdot \mathrm{mol}^{-1}$ & $\bar{n}$ & $\mathrm{~K}_{2}, \mathrm{~L}_{\mathbf{m}} \mathrm{mol}^{-1}$ & $\mathrm{~K}_{3}, \mathrm{~L}^{2} \cdot \mathrm{mol}^{-2}$ \\
\hline Bidibopp & 2.8147 & 699 & $1.50 \pm 0.23$ & 3 & 9 \\
\hline IPA & 2.9646 & 680 & $1.50 \pm 0.19$ & 6 & 10 \\
\hline UPA & 4.17 & & $1.20 \pm 0.14$ & 2 & 0 \\
\hline EHPA & 2.3785 & 847 & $1.20 \pm 0.12$ & 4 & 0 \\
\hline
\end{tabular}


Tableau 8: Partition coefficients (P) of the monomeric form of organophosphorus acids (HL) between an organic phase containing 0,1 mol. $\mathrm{L}^{-1} \mathrm{HL}$ in $\mathrm{n}$-dodecane and 1 mol. $\mathrm{L}^{-1} \mathrm{HCl}$ (temperature $=25{ }^{\circ} \mathrm{C}$ ). Partition coefficients have been calculated by using Eq. 22 and constants reported in Tables 6 and 7.

\begin{tabular}{cc}
\hline HL & P \\
\hline Cyanex272 & 657 \\
Cyanex301 & 1231 \\
Ionquest801 & 88 \\
D2EHPA & 211 \\
Bidibopp & 40539 \\
IPA & 34873 \\
TPA & 30000 \\
UPA & 13252 \\
EHPA & 31723 \\
\hline
\end{tabular}




\section{FIGURES}
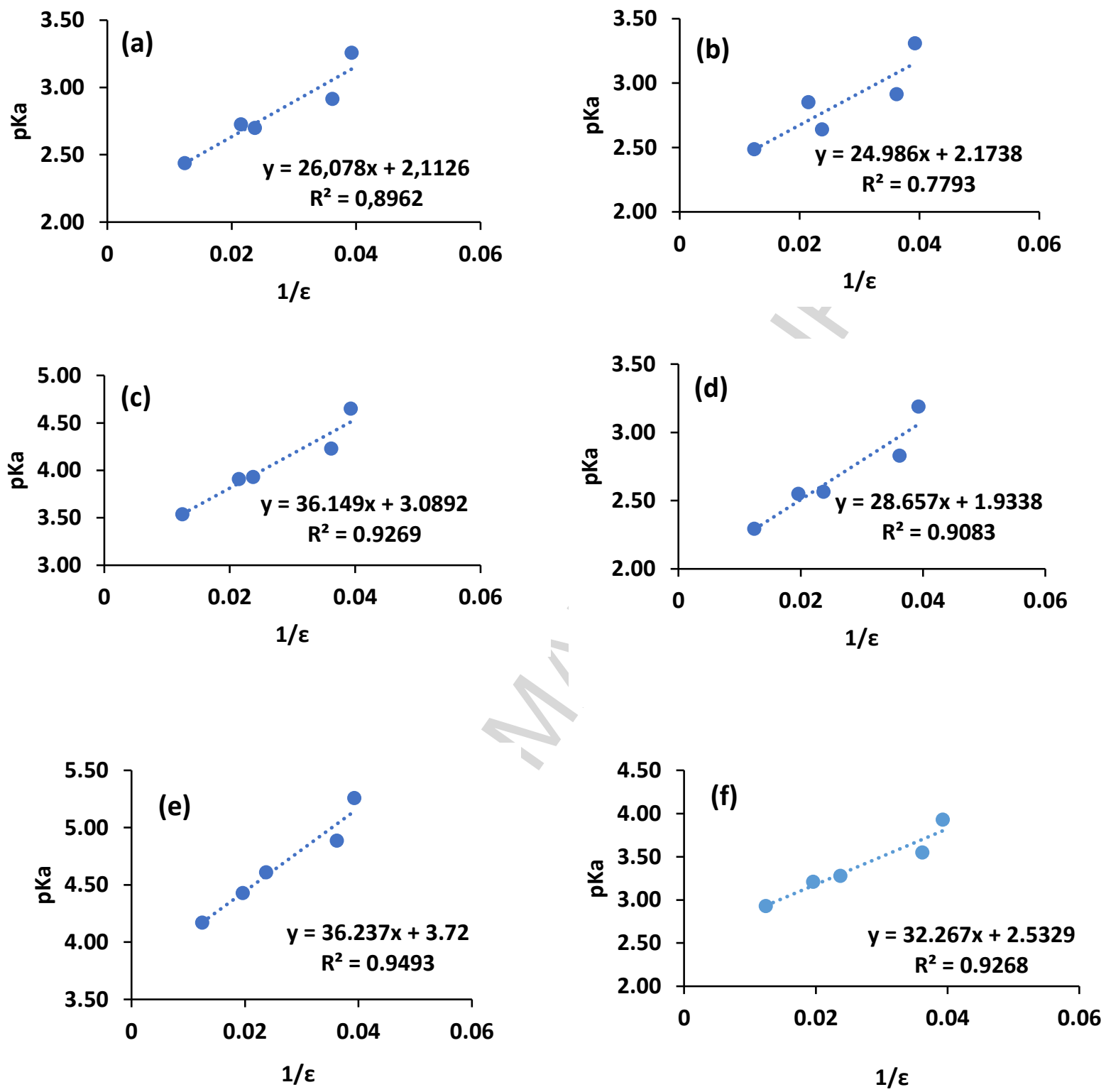

Figure 1: Variation of $\mathrm{pK}_{\mathrm{a}}$ as a function of $1 / \varepsilon$ for (a) Bidibopp, (b) IPA, (c) UPA, (d) TPA, (e) Cyanex 272, (f) D2EHPA in water/2-propanol mixtures (temperature $=25^{\circ} \mathrm{C}$ ). 

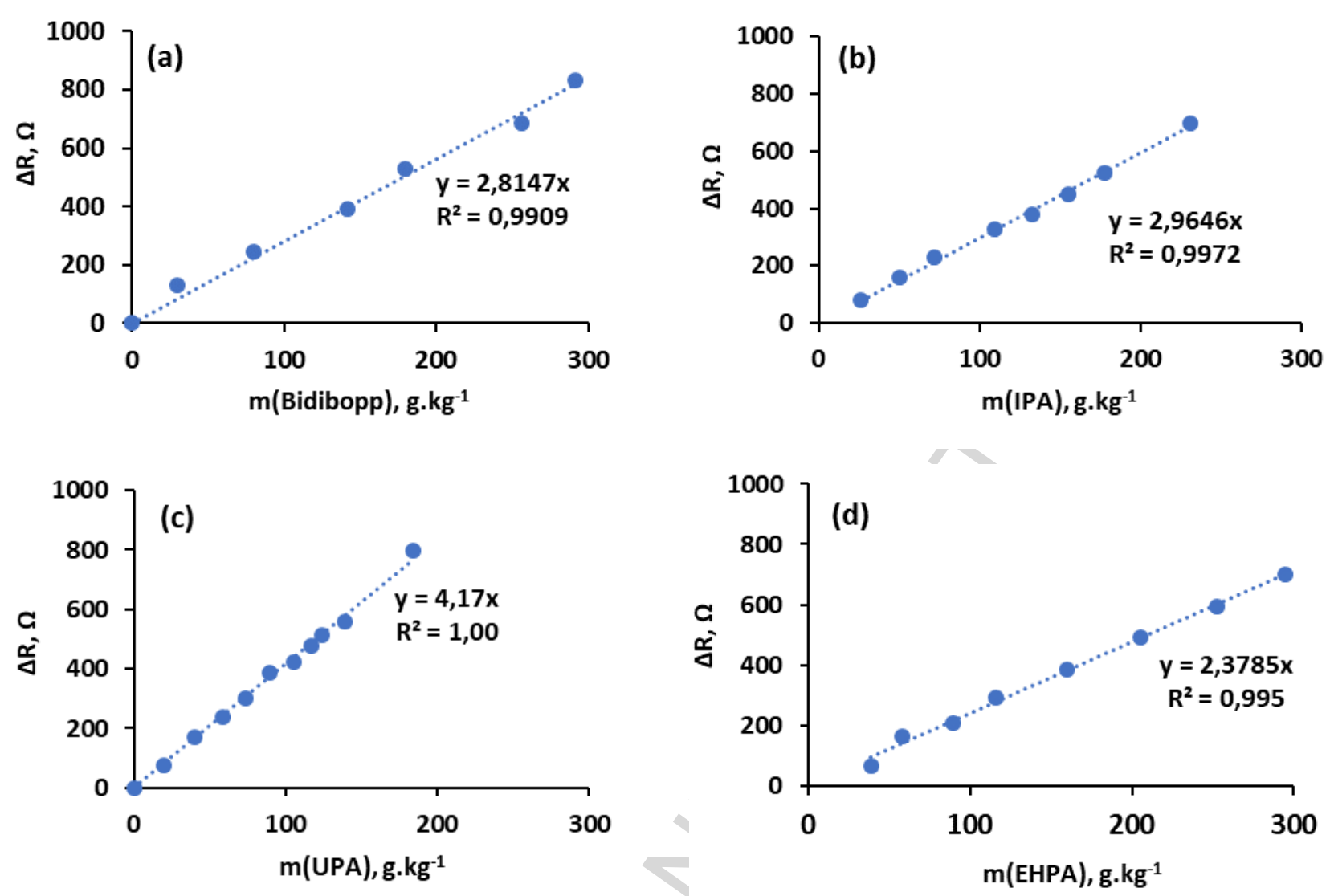

Figure 2: Difference in resistance between the thermistor $(\Delta \mathrm{R})$ measured during VPO experiments plotted as a function of the total solute concentration for (a) Bidibopp, (b) IPA, (c) UPA, (d) EHPA diluted in n-heptane (temperature $=25^{\circ} \mathrm{C}$ ). 

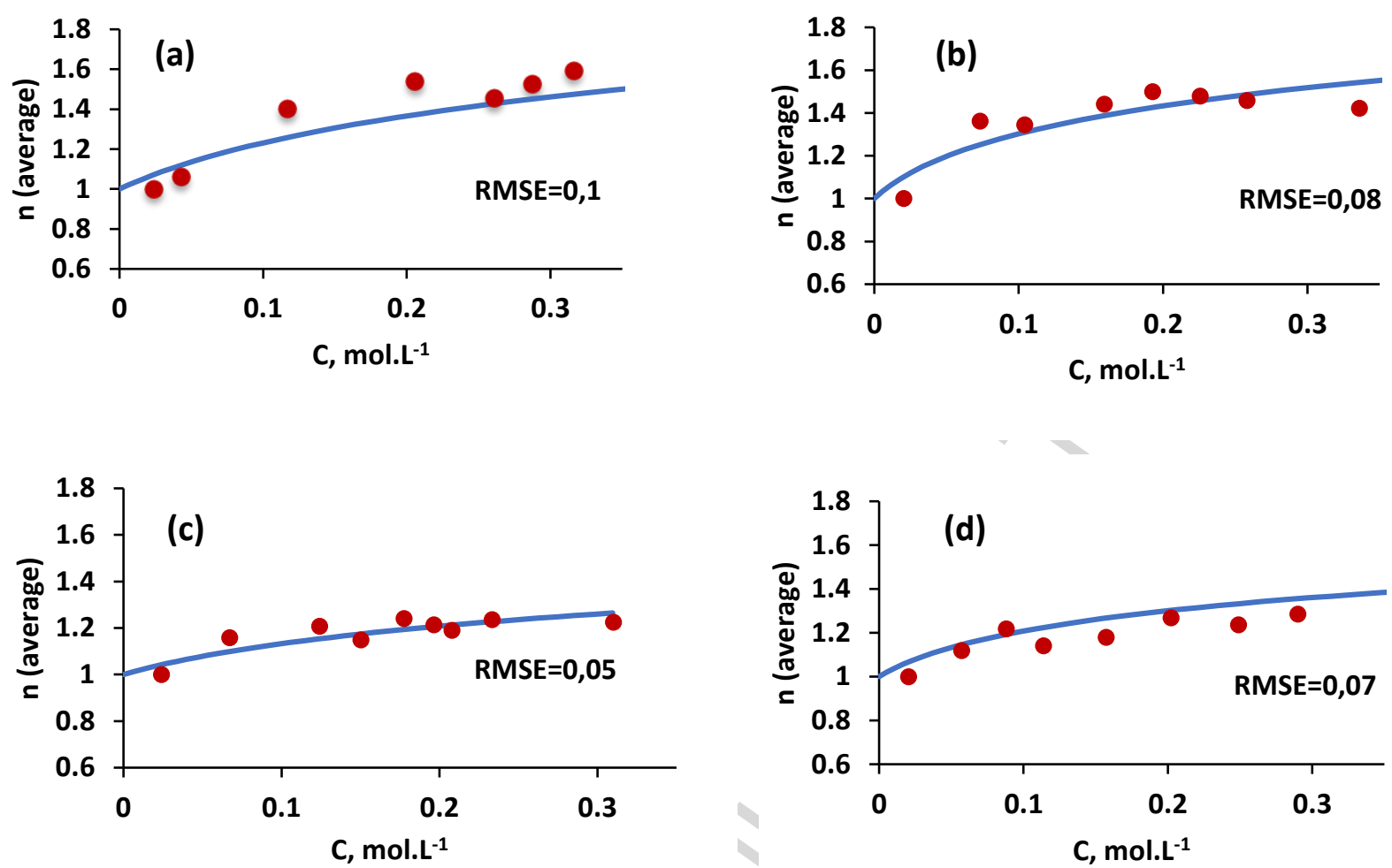

Figure 3: Aggregation number as a function of the total organophosphorus acid concentration for (a) Bidibopp, (b) IPA, (c) UPA, (d) EHPA diluted in n-heptane (temperature $=25^{\circ} \mathrm{C}$ ). The full drawn lines were calculated by using the dimerisation and trimerisation constants reported in Table 7. 

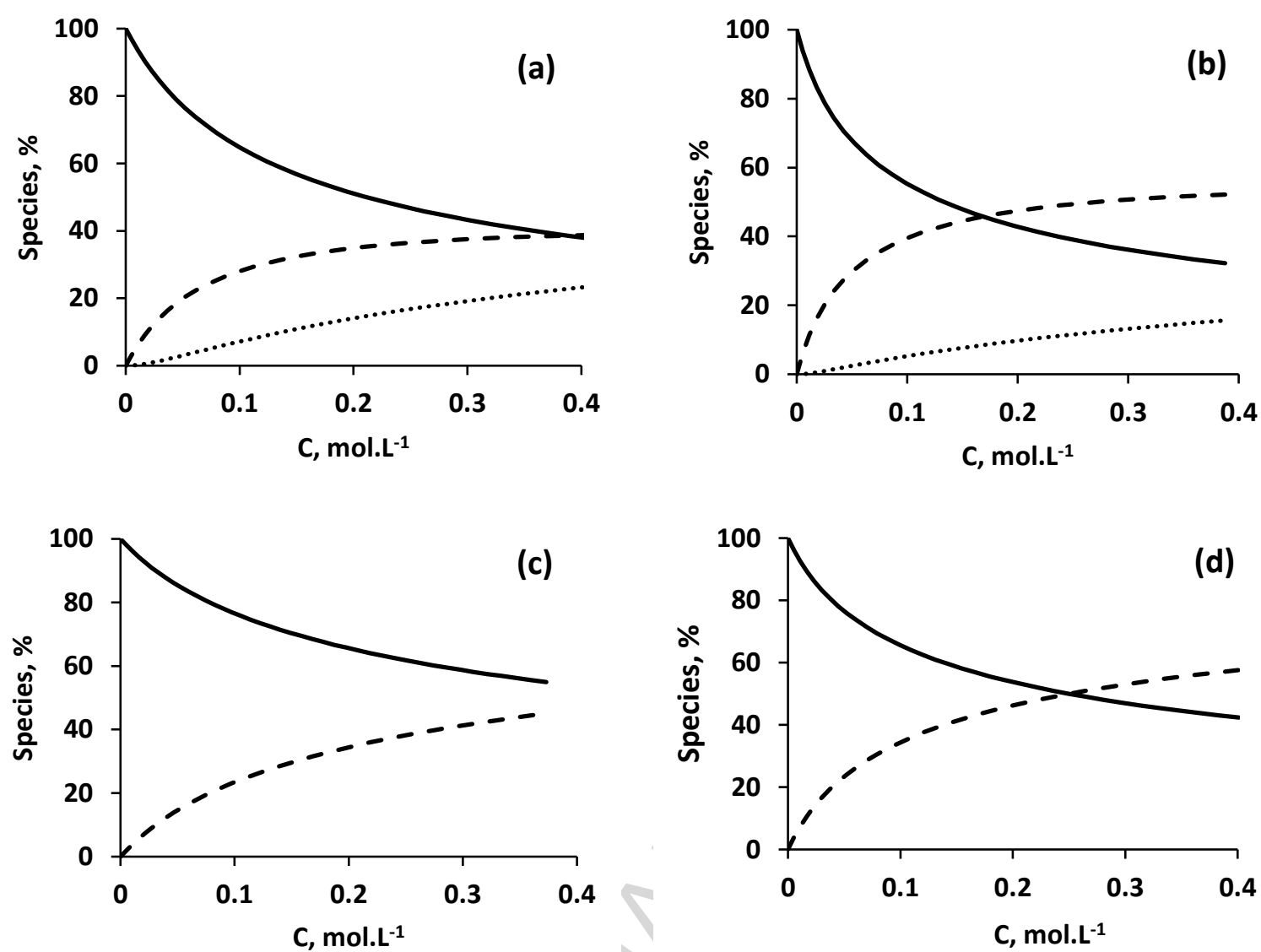

Figure 4: Aggregation distribution diagrams as a function of the total concentration of (a) Bidibopp, (b) IPA, (c) UPA, (d) EHPA diluted in n-heptane (-: monomer, ---: dimer, $\cdots$ : trimer; temperature $=25{ }^{\circ} \mathrm{C}$ ). 


\section{Highlights}

- Acidic properties and aggregation behaviour of extractants have been determined by potentiometry and VPO measurements.

- Steric hindrance destabilizes the aggregates

- The presence of oxygen atoms in the alkyl chains of the extractants is responsible for a decrease of the pKa values. 